\title{
A Review of the Health Implications of Heavy Metals in Food Chain in Nigeria
}

\author{
Ugonna C. Nkwunonwo $\mathbb{D}^{1}{ }^{1}$ Precious O. Odika $\mathbb{D}^{2}$ and Nneka I. Onyia $\mathbb{D}^{3,4}$ \\ ${ }^{1}$ Department of Geoinformatics and Surveying, University of Nigeria, Enugu Campus, Nsukka, Nigeria \\ ${ }^{2}$ Department of Geological Sciences, Nnamdi Azikiwe University, Awka, Nigeria \\ ${ }^{3}$ Faculty of Environmental Sciences, Enugu State University of Science and Technology, Enugu, Nigeria \\ ${ }^{4}$ Women's Union, Diocese of Nike, Church of Nigeria, Anglican Communion, Enugu, Nigeria \\ Correspondence should be addressed to Ugonna C. Nkwunonwo; ugonna.nkwunonwo@unn.edu.ng
}

Received 1 October 2019; Revised 14 February 2020; Accepted 21 February 2020; Published 16 April 2020

Academic Editor: Claudio Cameselle

Copyright (c) 2020 Ugonna C. Nkwunonwo et al. This is an open access article distributed under the Creative Commons Attribution License, which permits unrestricted use, distribution, and reproduction in any medium, provided the original work is properly cited.

\begin{abstract}
Heavy metals such as $\mathrm{Zn}, \mathrm{Pb}, \mathrm{Fe}$, and $\mathrm{Cu}$ are abundant in the environment and contribute largely to the sustainability and equilibrium of ecosystem processes. However, because of their bioaccumulation, nondegradability, and the excessive amounts in which they exist, these metals contaminate the food chain and subsequently become a source of toxicity to human beings and the entire ecological function. This is a major issue of concern within the study of environmental science and geochemistry. Although there is a global significance to the issue, it seems more immediate for the developing countries (DCs) such as Nigeria, where the pressure of the teeming population escalates the exigency for human sustainability, food security, and total eradication of hunger. Within the Nigerian context, many studies have examined this all-important issue, but most of these studies are fragmented and limited within the purview of mostly individual states and localities within the country. Taken on a wider geographical scale, the discussions and perspectives of these studies on heavy metal contamination of the food chain offer insufficient insight and expose merely a snapshot of the actual situation. As a result of this, a country-wide knowledge base of the implications of heavy metals on the food chain is lacking. Thus, the present study synthesises existing literature and their findings to create a knowledge base on the vulnerability of the food chain in Nigeria. Aquatic foods, fruits, vegetables, and major staple food such as tubers are the major host of carcinogenic and mutagenic components of heavy metals in Nigeria. This study motivates the Standard Organisation of Nigeria (SON), along with other food and agricultural agencies, to intensify their efforts in monitoring and analysing food components, and we advise consumers to eat with certain degrees of caveat.
\end{abstract}

\section{Introduction}

Since his famous publication titled, "What is a heavy metal?," Hawkes [1] has spurred far greater interests for more and more debates within environmental science, geochemistry, and toxicology research. Although Hawkes' study, from the stand point of natural and pure sciences research, primarily constructed a theoretical paradigm that lays the foundation for a critical understanding of heavy metals, it has definitely instigated a rising academic discussion, which now focuses on the abundance and implications of heavy metals within the human-ecological systems. Hawkes' study is also a seminal tool to drive a deeper and more cognate exploration of heavy metals. The context by which he introduced and expounded heavy metals as the block of metals and metalloids found in Groups 3 to 16 and in Periods 4 and greater of the periodic table makes sense to conclude that a metal is heavy not necessarily because of its density, rather its chemistry. This has remained a building block which various studies, in environmental science literature, have used to define heavy metals comprising metals and metalloids which are associated with adverse environmental effects, mostly pollution, toxicity, and contamination. Still, the diversity of definitions accorded to heavy metals in the literature creates an ideological conflict because of the dominance of density, relative atomic mass, and atomic number in the conceptualisation of heavy metals. 
Recently, Ali and Khan [2] argued on a more comprehensive idea which suggests that heavy metals are naturally occurring metals having an atomic number greater than 20 and an elemental density greater than $5 \mathrm{gcm}^{-3}$. The study provided a list of fifty one elements that it referred to as heavy metal$s$ - with the exclusion of tin and arsenic. Obviously, there is an active debate on the conceptualisations of heavy metals which, needless to say, is not the focus of this study. However, many ideas drawn from extant research are logical pointers to what might be the likely implications of heavy metals on the food chain.

Basically, heavy metals are unarguably the transition and posttransition metals, and the examples which are common in various literature are lead $(\mathrm{Pb})$, cadmium $(\mathrm{Cd})$, vanadium $(\mathrm{V})$, cobalt $(\mathrm{Co})$, chromium $(\mathrm{Cr})$, copper $(\mathrm{Cu})$, iron $(\mathrm{Fe})$, arsenic (As), nickel (Ni), manganese (Mn), tin (Sn), zinc $(\mathrm{Zn})$, and mercury $(\mathrm{Hg})$. The availability and accessibility of these metals and metalloids through natural and anthropogenic pathways remain a major global concern in the ecosystem [3-5]. The sources of heavy metals in the surface environment are natural and anthropogenic. Natural sources include parent rocks and metallic minerals. Anthropogenic sources include agriculture (fertilizers, pesticides, etc.), metallurgy (mining, smelting etc.), energy production (power plant, leaded gasoline, etc.), and sewage disposal $[6,7]$. A study at Ishiagu in Nigeria showed that while the $\mathrm{Pb}-\mathrm{Zn}$ deposit is the natural source of heavy metals in the area, anthropogenic sources (from the use of power plants) could also be significant as power plants have been up to the time of the study the only source of electricity in the area [7]. In the North China Plain, the application of farmyard and chemical fertilizer was the pathway through which some heavy metals migrated into the soil [8]. In assessing the sources of heavy metals in the surface environment in a study area, anthropogenic activities of the habitants remain a major factor. In Nigeria, mining of ore deposits, oil and gas exploration and exploitation, and agriculture, besides manufacturing, construction, and production activities are among the several commercial and artisanal extractions of natural resources, capable of influencing the disruption, dispersion, and distribution of naturally placed heavy metals and metalloid to the environment [9]. These metals and metalloid are further influenced by the conditions of the environment of deposition such as acidity, alkalinity, $\mathrm{pH}$, adsorption, speciation, and temperature which inform their solubility, mobility, availability, and accessibility. They also make their way into the different environmental media such as soil, water, rock, and sediment from which we grow most of our food.

The chemistry of heavy metals is a major contribution to their implications within the human-ecological context. In terms of usefulness, the universe had been largely blessed by the abundance of heavy metals and the roles they play both in keeping the equilibrium and sustainability of ecosystem functions [10-12]. For example, Fe which is the most abundant metal on Earth and very electropositive can combine easily with $\mathrm{O} 2$ (oxygen gas) and thus forms a rich compound for industrial and biological purposes [13]. In their experimental research, Bae et al. [14] assiduously showed the crucial roles that $\mathrm{Zn}$ plays in dermatology. $\mathrm{Cu}$ is effectively used in the treatment for fish diseases [15] and to treat radiation sickness [16]. Nagajyoti et al. [17] argued that in trace amounts, most of the heavy metals are of significance to plant metabolism. However, these metals and metalloids adversely affect lives in the ecosystem, including humans, plants, and animals through their bioaccumulation and bioaugmentation in the food chain $[18,19]$. Alkorta et al. [20] and Volesky [21] were of the opinion that most heavy metals are toxic even at low concentration of about 0.1 to $0.3 \mathrm{mg} / \mathrm{l}$. However, $\mathrm{pH}$ level plays a vital role in heavy metal ion adsorption from an aqueous solution, and speciation and adsorption level influence the mobility of these metals [22]. The soil type can also influence adsorption of heavy metals; for instance, soil clay minerals have a greater influence on adsorption and inactivation compared with soil organic matter [23].

In view of these impacts, Ali et al. [24] observed that some heavy metals possess the ability to disrupt metabolic activities and genetic makeup, while others affect embryonic or foetal development. This often results in cancer, developmental disorders, and neurological and behavioural changes often found in children. So, the health impacts of heavy metals on the food chain, which include the soil, plants, and aquatic life, cannot be more obvious. As a major source of human exposure to heavy metal toxicity, the food chain is a critical component that now draws the attention of major discussions within the academy of nutritional and environmental sciences (see, for example, [25-27]). With the increasing human populations and rising issues of food insecurity which have heightened the demand for genetically engineered food, it is now ever more crucial that current research should examine the typology of heavy metals found in the food chain and the pathway in which these metals contaminate a range of staple foods consumed by many people within the diversity of geographical contexts.

This study focuses on the negative impacts of heavy metals and metalloids in the food chain regarding their total concentration levels in the environment in Nigeria. With the early industrialisation stage in Nigeria and poor implementation of environmental protection policies and regulations, its environmental pollution and contamination have been a great concern. According to Onakpa et al. [28], both natural and anthropogenic sources are pathways by which heavy metals and metalloids contaminate many Nigeria food crops and vegetables. Previous studies on the health implications of heavy metals are fragmented and mostly focused on individual states and localities within Nigeria [29-31]. The findings of these studies are consistent with the general view that heavy metals are nonbiodegradable, and metallic elements with relatively high density are toxic or poisonous even at low concentrations. They accumulate in the environment and over time contaminate the food chain, which is a major source of environmental and human health risk $[1,24,32,33]$. Despite the obvious significance of these studies, a country-wide knowledge base of the implication of heavy metals on the food chain within different regional and socioeconomic settings of Nigeria is lacking. This is a major gap in science, which this review makes efforts to address. It provides important insight into the toxicity of heavy metals 
and the particular foods that are increasingly vulnerable to heavy metals and hazardous for consumption with respect to different geographical regions in Nigeria. The authors synthesise the findings of the current studies to create a knowledge base which somewhat simplifies an understanding of the impacts of heavy metals on the food chain within the context of Nigeria. Given the high population of Nigeria, its extreme poverty level, and environmental and public health challenges [34], food availability and consumption are key factors to its continuous existence. Therefore, research must inform decision towards ensuring that health and sustainability are core in the choice of foods that Nigerians consume. This will mitigate several health issues that constrain economic and human capital development within the country.

\section{Methods and Data}

To achieve the objectives of this review, the authors conducted a structured search process to identify the body of the current literature relevant to the study. In collecting relevant literature, the authors ensured that they maintained quality and academic standard, which are often the basis of most literature review studies, for example, Manikas and Hansen [35]; Nkwunonwo et al. [36]; Thonemann and Schumann [37]. Therefore, the present literature search considered mainly research articles published in highly reputed journals (indexed by Scopus and Scimago and ranked in Thompson Reuter). The authors consulted EBSCO's environmental database, which hosts top open access environmental research journals: Greenfile, which archives well-researched debates covering all aspects of human impact on the environment. The study also considered several other libraries including DOAJ (Directory of Open Access Journals) digital Library, Google Scholar, PubMed, E-resources, IEEE Explore, SpringerLink, ScienceDirect, and Thomson Reuters' Web of Science. Key terms such as "heavy metals," "food chain," and "food poisoning," along with the combination of terms such as "heavy metal in Nigeria," "heavy metal and food chain in Nigeria," "heavy metals and health in Nigeria," and "heavy metals and food chain contamination" were applied to the search. Authors adopted the idea by Manikas and Hansen [35], with which they designed and applied a set of five inclusion and exclusion criteria: (1) the literature should address heavy metals as an area of core research, (2) the literature must be a research paper, i.e., being published after a rigorous peer review, (3) the language expressed in the selected article must be English, (4) the literature must not be more than ten years of age from the time of the present research, except when it is a seminal study, and finally (5) the literature must be none of these: an abstract with extended perspective, short communications, letters, and presentations. Although authors relished bringing in the global focus of environmental geochemistry and heavy metal toxicity, they maintained that a good number of the sourced studies must focus on heavy metals in Nigeria. With this aim, the study had to consider some locally based journals in situations where local ideas seemed unassailable and inevitable, but authors made sure that they maintained the same criteria for exclusion and inclusion.

On the whole, studies derived from the literature search have acknowledged the richness and usefulness of heavy metals within the human-ecological system. It also acknowledged significantly the negative implications of these metals, especially in the food chain. Discussions on the toxicity of heavy metals also include the means to assess and mitigate these impacts. Though Kumar et al. [38] discussed the process of phytoextraction, Ali et al. [24] presented phytoremediation of heavy metals. It also shows that other methodologies including photocoagulation [39], biosorption [40], and rhizofiltration [41] have been found in the extant research literature. These are proven scientific techniques that have now formed the basis of best practices in the study of the impacts of heavy metals on the food chain system. Finally, the literature search shows that despite the wide-ranging discussions on heavy metals and food chain, research has developed little regarding the application of more scientific techniques to mitigate the heavy metal impacts on the food chain in Nigeria.

\section{Results and Discussion}

Nigeria is one of the DCs facing massive environmental contamination through natural constituents such as heavy metals and metalloids. The concentration levels of heavy metals alongside their bioavailability and bioaccessibility can cause contamination of trophic levels, as shown in Table 1. This table also shows different regions where foods could serve as good dietary sources due to essential trace metals, besides the levels for human consumption safety margin. Animals, leafy vegetables, and fruits are consumed widely because of their nutritional value and culinary purposes. Therefore, they are part of the daily diet in many Nigerian households. The consumer's perception determines the quality of such food and vegetables. Although, this perception is subjective, it is mostly based on the measure of the colouration and leaf size of vegetables. Hence, there is a general assumption that vegetations with dark green and big leaves are of better quality. However, Mapanda et al. [63] have shown that external morphology is inadequate for leafy vegetables qualitative assessment as heavy metals rank high amongst the major contaminants. In the soil, heavy metal accumulation depends on plant species. However, the efficiency of plants in absorbing metals is determined by either plant uptake or soil-to-plant transfer factors of the metals. Plant tissues absorb and accumulate heavy metals based on the available $\mathrm{pH}$, moisture content, temperature, organic matter, and nutrient [64]. Table 2 shows some risks associated with food chain contamination for humans and some trophic levels in Nigeria.

\section{Potential Health Hazards of Some Selected Heavy Metals and Metalloids}

4.1. Lead $(\mathrm{Pb})$. Toxicological review of lead has shown inhibition of the activity of $d$-aminolaevulinic dehydratase (porphobilinogen synthase, one of the major enzymes 
TABle 1: Regional environmental contamination of some selected trophic levels in Nigeria.

\begin{tabular}{|c|c|c|c|c|}
\hline \multirow{2}{*}{ Region } & \multicolumn{3}{|c|}{ Some selected trophic level } & \multirow{2}{*}{ Author(s) } \\
\hline & Producers (plants/crops) & Herbivores & Carnivores & \\
\hline $\begin{array}{l}\text { East } \\
\text { Examples: } \\
\mathrm{Pb}, \mathrm{Cd} \text {, and Ni concentrations } \\
\text { in food crops and fruits in } \\
\text { Owerri, Imo State, exceeded } \\
\text { maximum acceptable levels for } \\
\text { agricultural soil } \\
\text { Potential lead contamination } \\
\text { in food crops in Anambra and } \\
\text { Ebonyi States } \\
\text { Traces of heavy metals were } \\
\text { found in bouillon cubes and } \\
\text { food condiments in Umuahia, } \\
\text { Abia State } \\
\text { Pb-contaminated cassava } \\
\text { tuber and lemon grass and } \\
\text { Mn-contaminated leafy } \\
\text { vegetable in Enyigba, Ebonyi } \\
\text { State }\end{array}$ & $\begin{array}{l}\text { Oryza sativa, Glycine max, } \\
\text { Pentabacta microfila, } \\
\text { Canarium schweinfurthii, } \\
\text { Citrus reticulate, and Ananas } \\
\text { comosus were contaminated by } \\
\mathrm{Pb}, \mathrm{Cd} \text {, and } \mathrm{Ni} \text { in soil in } \\
\text { Owerri. Oryza sativa in soil in } \\
\text { Enugu State showed a } \mathrm{Pb} \text { and } \\
\text { Cd total hazard index of }>1 . \\
\text { Studies have also revealed } \mathrm{Pb} \\
\text { exceedance in Prosopis } \\
\text { africana, Xylopia aethiopica, } \\
\text { Piper gineense, Monodora } \\
\text { myristica, and Capsicum } \\
\text { frutescens. Others include } \\
\text { cassava and lemongrass }\end{array}$ & $\begin{array}{l}\text { Goat, } \\
\text { rodents, } \\
\text { cattle }\end{array}$ & Fish, crabs, bird, bear & $\begin{array}{c}\text { Orisakwe et al. [31]; } \\
\text { Ihedioha et al. [9]; } \\
\text { Asomugha et al. [42]; } \\
\text { Okoronkwo et al. [43]; } \\
\text { Nnorom et al. [44]; Obiora } \\
\text { et al. [29]; Ihedioha and } \\
\text { Okoye [45] }\end{array}$ \\
\hline $\begin{array}{l}\text { South } \\
\text { Examples: green vegetables } \\
\text { showed higher concentrations } \\
\text { of heavy and trace metals than } \\
\text { other crops in Rivers State. } \\
\text { Hart et al. [46] posted higher } \\
\text { concentrations of } \mathrm{Zn}, \mathrm{Cd}, \mathrm{Pb} \text {, } \\
\mathrm{Fe}, \mathrm{Cu}, \mathrm{Cr}, \mathrm{Co} \text {, and } \mathrm{Mn} \text { in } \\
\text { crops grown in oil-producing } \\
\text { areas than those from crops in } \\
\text { nonoil-producing areas }\end{array}$ & $\begin{array}{l}\text { Okra and cocoyam with } \\
9.1 \mathrm{mg} / \mathrm{kg} \text { and } 1.1 \mathrm{mg} / \mathrm{kg} \text {, } \\
\text { respectively, in oil exploration } \\
\text { sites in Rivers State. Other } \\
\text { crops include cassava and } \\
\text { plantain, which showed higher } \\
\text { concentration of } \mathrm{Cr}, \mathrm{Cu}, \mathrm{Pb} \text {, } \\
\mathrm{Fe} \text {, and } \mathrm{Zn} \text { around Etelebou } \\
\text { Oil Flow Station in Bayelsa } \\
\text { State, indicating long-term } \\
\text { accumulation of these heavy } \\
\text { metals in soil }\end{array}$ & $\begin{array}{c}\text { Goat, cattle, } \\
\text { ram }\end{array}$ & $\begin{array}{l}\text { Fish, periwinkle and other } \\
\text { sea foods, bird. Heavy } \\
\text { metals in fish (Clarias } \\
\text { gariepinus) organs from } \\
\text { Asaba major markets, Delta } \\
\text { State, Nigeria }\end{array}$ & $\begin{array}{l}\text { Kelle et al. [47]; Hart et al. } \\
\text { [46]; Worgu [48]; Alum } \\
\text { et al. [49]; Nkwocha et al. } \\
\text { [50]; Nkpaa et al. [51] }\end{array}$ \\
\hline $\begin{array}{l}\text { West } \\
\text { Examples: higher heavy metal } \\
\text { concentrations in Amaranthus } \\
\text { grown on Lagos highway soil } \\
\text { than in those from controlled } \\
\text { soil. Higher concentration of } \\
\text { heavy metals and metalloids in } \\
\text { the plant organs cultivated on } \\
\text { Ekiti dumpsites in addition to } \\
\text { seasonal variation of heavy } \\
\text { metal concentration levels } \\
\text { (suggesting element mobility } \\
\text { heavy metal adsorption by } \\
\text { plants) }\end{array}$ & $\begin{array}{l}\text { Amaranthus, groundnut, } \\
\text { maize grains, spinach, roselle } \\
\text { leaves, okra, onions. In Ekiti, } \\
\text { Ni concentration level in okra } \\
\text { reduced by } 45.19 \% \text { in rainy } \\
\text { season while Fe by } 8.25 \% \text {. } \\
\text { There is also potential } \\
\text { contamination of Pb, } \mathrm{Zn} \text {, and } \\
\mathrm{Hg} \text { in these vegetables }\end{array}$ & $\begin{array}{l}\text { Cattle, ram, } \\
\text { goat, }\end{array}$ & Fish, bird, bear & $\begin{array}{c}\text { Nduka et al. [52]; Adeyeye } \\
\text { [53]; Zhou et al. [54]; } \\
\text { Olayiwola et al. [55]; } \\
\text { Ogunkunle et al. [56] }\end{array}$ \\
\hline
\end{tabular}


TABle 1: Continued.

\begin{tabular}{|c|c|c|c|c|}
\hline \multirow{2}{*}{ Region } & \multicolumn{3}{|c|}{ Some selected trophic level } & \multirow{2}{*}{ Author(s) } \\
\hline & Producers (plants/crops) & Herbivores & Carnivores & \\
\hline $\begin{array}{l}\text { North } \\
\text { Examples: heavy metals such } \\
\text { as Pb and Cd have been found } \\
\text { to be highly toxic (exceeding } \\
\text { the World Health } \\
\text { Organisation (WHO) and the } \\
\text { Food and Agriculture } \\
\text { Organisation (FAO) } \\
\text { maximum permissive limits) } \\
\text { in farms in Kaduna and Kano } \\
\text { metropolis. Higher heavy } \\
\text { metal concentration in soils } \\
\text { from the Itakpe iron ore } \\
\text { mining site than those from } \\
\text { controlled soil in Kogi State. } \\
\text { Some of the heavy metals in } \\
\text { both mining and nonmining } \\
\text { sites had concentration below } \\
\text { the WHO/FAO maximum } \\
\text { permissive limit for food }\end{array}$ & $\begin{array}{l}\text { Contaminated spinach, jute } \\
\text { mallow, and tomatoes in } \\
\text { Kaduna and Kano farms by } \mathrm{Pb} \\
\text { and cadmium. Permissive } \\
\text { concentration levels of } \mathrm{Cu} / \mathrm{Zn} \text {, } \\
\text { respectively, in peppers }(5 / \\
13.5 \mathrm{mg} / \mathrm{kg}) \text {, tomatoes }(5.5 / \\
15.5 \mathrm{mg} / \mathrm{kg}) \text {, and onions }(4 / \\
16.75 \mathrm{mg} / \mathrm{kg}) \text { in soils at Itakpe }\end{array}$ & $\begin{array}{l}\text { Cattle, ram, } \\
\text { goat, donkey }\end{array}$ & $\begin{array}{l}\text { Bird, panda, catfish (UKE } \\
\text { Stream in Nasarawa State), } \\
\text { Clarias and tilapia in Lake } \\
\text { Geriyo, Adamawa State. }\end{array}$ & $\begin{array}{c}\text { Bawuro et al. [57]; Jacob and } \\
\text { Kakulu [58]; Matthews- } \\
\text { Amune and Kakulu [59]; } \\
\text { Iyaka [60]; Opaluwa et al. } \\
\text { [61] }\end{array}$ \\
\hline
\end{tabular}

A general review of heavy metal concentration and potential health implications of beverages consumed in

Nigeria. Heavy metal concentrations, including iron, mercury, tin, antimony, cadmium, zinc, copper, chromium, lead, and manganese, seldom exceed the maximum contaminant level recommended by the Standard Organisation of Nigeria (SON) and the World Health Organisation (WHO) as applicable to drinking water resources

Izah et al. [62]

involved in the biosynthesis of heme) and developmental problems such as impaired cognitive function, behavioral disorder, stunted growth, and impaired hearing at blood lead level as low as $5 \mu \mathrm{g} / 1[9,78]$. Lead also interferes with calcium metabolism, both directly and by interfering with vitamin $\mathrm{D}$ metabolism; it concentrated largely in bones in animals and humans and interferes with the normal maturation of erythroid elements in the bone marrow [79]. These effects have been observed in children at blood lead levels ranging from 12 to $120 \mu \mathrm{g} / \mathrm{l}$. Lead is toxic to both the central and peripheral nervous systems, inducing subencephalopathic neurological and behavioral effects. Other effects include epidemiological effects (blood lead level of $30 \mu \mathrm{g} / \mathrm{l}$ ), intelligence quotient deficits of about four points in children due to prenatal/postnatal exposure to lead (blood lead level ranging from 11 to $33 \mu \mathrm{g} / \mathrm{l}$ ), headache, irritability, constipation, weight loss, fatigue, hypertension, miscarriages, stillbirths, and renal tumors [80]. However, there is evidence from studies in humans that adverse neurotoxic effects other than cancer may occur at very low concentrations of lead, and that a guideline value derived on this basis would also be protective for carcinogenic effects [81]. A report of prevalence dental caries in children in the Tamar Valley, England, and in Ceredigion, Wales, was associated with a high level of $\mathrm{Pb}$ in soils which were available to plants [79].

4.2. Manganese $(\mathrm{Mn})$. Adverse effects of $\mathrm{Mn}$ can result from both deficiency and overexposure, causing neurological effects due to high level in drinking water, which can cause tremor, gait disorders (seen in primate), psychological symptoms such as irritability, and emotional liability [80]. For instance, amyotrophic lateral sclerosis, according to Hubbs-Tait et al. [80], is a progressive neurological disorder, which appears to be a disease that may reflect a deficiency of $\mathrm{Mg}$ or $\mathrm{Mn}$. The decreased intake of $\mathrm{Mg}$ or Mn leads to a decreased ability to store and use thiamin (vitamin $B_{1}$ ). These authors further noted that there is some evidence suggesting that Parkinson's disease may be casually related to Mn, but in this case, to an excess of it.

4.3. Nickel (Ni). Nickel is an essential trace element in animals. Some of its health risk includes fibrosis, chronic bronchitis, impaired pulmonary function, and emphysema [82]. Allergic contact dermatitis is the most prevalent effect of toxicity of nickel in the general population [78]. However, it is suspected to be an essential element for some plants and animals [83]. According to Plant and Thornton [84] and Carla [85], Ni deficiency results in decreased plasma cholesterol, increased liver cholesterol, ultrastructural changes in the liver calls, rough hair, impaired reproduction, and poor growth of the offspring.

4.4. Zinc ( $\mathrm{Zn})$. Zinc is an essential trace element whose threshold value in surface and groundwater normally do not exceed 0.01 and $0.05 \mu \mathrm{g} / \mathrm{l}$, respectively [86]. However, concentrations in tap water can be much higher as a result of dissolution of zinc from pipes. It should be noted that drinking water containing zinc levels above $3 \mu \mathrm{g} / \mathrm{l}$ may not be acceptable for consumers [87]. 
TAвLE 2: Risk/implications of food chain contamination for humans, domestic life, and wildlife in Nigeria.

\begin{tabular}{|c|c|c|c|c|}
\hline Region & $\begin{array}{c}\text { Common heavy } \\
\text { metals }\end{array}$ & Major sources & Risk/implications & Author \\
\hline East & $\begin{array}{l}\mathrm{Pb}, \mathrm{Al}, \mathrm{Zn}, \mathrm{Cr} \\
\mathrm{Fe}, \mathrm{Mn}, \mathrm{Cu}, \mathrm{Co} \\
\quad \mathrm{As}, \mathrm{Ni}, \mathrm{Hg}\end{array}$ & $\begin{array}{l}\text { Heavy metals and metalloids from } \\
\text { municipal and industrial wastes in } \\
\text { Onitsha/Awka and Abagana in } \\
\text { Anambra and Abia States, } \\
\text { respectively, mining and quarrying } \\
\text { (e.g., Pb-Zn mining and igneous } \\
\text { rock quarrying and limestone } \\
\text { mining at Ishiagu and Nkalagu, } \\
\text { respectively, in Ebonyi State), air } \\
\text { pollution from transportation, } \\
\text { agrochemicals }\end{array}$ & $\begin{array}{l}\text { Potential heavy metal toxicity in the } \\
\text { body system that can lead to } \\
\text { hemoglobinuria, gastrointestinal } \\
\text { disorders, ataxia, pneumonia, } \\
\text { diarrhoea, stomatitis, and paralysis }\end{array}$ & $\begin{array}{c}\text { Orisakwe et al. [31]; Ihedioha et al. } \\
\text { [9]; Asomugha et al. [42]; Odika } \\
\text { et al. [7]; Jaishankar et al. [65]; } \\
\text { Nduka et al. [52] }\end{array}$ \\
\hline South & $\begin{array}{l}\mathrm{Zn}, \mathrm{Cd}, \mathrm{Pb}, \mathrm{Fe}, \\
\mathrm{Cu}, \mathrm{Cr}, \mathrm{Co} \text {, and } \\
\mathrm{Mn}\end{array}$ & $\begin{array}{l}\text { Petroleum extraction and refineries, } \\
\text { e.g., consumers of seafood from } \\
\text { these contaminated sites in } \\
\text { Ogoniland may be exposed to metal } \\
\text { pollution }\end{array}$ & $\begin{array}{l}\text { Environmental degradation } \\
\text { resulting to excessive social unrest } \\
\text { and destruction and incessant harm } \\
\text { to the physical, social, } \\
\text { environmental, and economic } \\
\text { health of its inhabitants }\end{array}$ & Nkpaa et al. [51]; Worgu [48] \\
\hline West & $\begin{array}{l}\mathrm{Pb}, \mathrm{Al}, \mathrm{Zn}, \mathrm{Cr} \\
\mathrm{Fe}, \mathrm{Mn}, \mathrm{Cu}, \mathrm{Co} \\
\mathrm{Mo}, \mathrm{Se}, \mathrm{As}, \mathrm{Ni} \\
\mathrm{Hg}\end{array}$ & $\begin{array}{l}\text { Aerial deposition by emissions from } \\
\text { Lagos traffic, leaching and runoffs of } \\
\text { contaminants from Ekiti State } \\
\text { dumpsites. Contaminated } \\
\text { freshwater bodies in Osun State. } \\
\text { Accumulation of heavy metals from } \\
\text { battery waste in topsoil, surface } \\
\text { water, and garden grown maize at } \\
\text { Omilende area, Olodo, Nigeria }\end{array}$ & $\begin{array}{l}\text { Long-term consumption of (leafy) } \\
\text { Amaranthus from Lagos highway } \\
\text { soils poses potential health risk due } \\
\text { to its heavy metal concentrations. } \\
\text { Health risk index (HRI) and daily } \\
\text { intake of metal (DIM) estimation } \\
\text { indicate higher health risk indexes } \\
\text { in vegetables containing Pb, Ca, and } \\
\text { Hg. Osun freshwater bodies showed } \\
\text { high carcinogenic risk from high } \\
\text { concentrations of heavy metals }\end{array}$ & $\begin{array}{c}\text { Atayese et al. [66]; Nduka et al. } \\
\text { [52]; Adeyeye [53]; Balkhair and } \\
\text { Ashraf [67]; Titilawo et al. [68]; } \\
\text { Afolayan [69] }\end{array}$ \\
\hline North: & $\begin{array}{l}\mathrm{Pb}, \mathrm{Zn}, \mathrm{Cr}, \mathrm{Fe} \\
\mathrm{Mn}, \mathrm{Cu}, \mathrm{Co}, \mathrm{Ni}\end{array}$ & $\begin{array}{l}\text { Some heavy metals are introduced } \\
\text { into the environment from } \\
\text { farmyard and chemical fertilizer } \\
\text { application (agrochemicals). Others } \\
\text { include domestic by-products, worn } \\
\text { automobile tires, roofs, brake } \\
\text { linings, and waste food. There are } \\
\text { also iron mining sites (Itakpe, Kogi } \\
\text { State). Sample of tested sediment } \\
\text { from the river Ngada, Maiduguri in } \\
\text { Borno State revealed provocative } \\
\text { amounts of heavy metals. Evidence } \\
\text { of mobility of heavy metals from } \\
\text { dumpsites to farmlands through } \\
\text { leaching and runoff in Lafia, } \\
\text { Nasarawa State }\end{array}$ & $\begin{array}{l}\text { Increase concentration of zinc in } \\
\text { pasture fields. Anthropogenic } \\
\text { sources usually produce heavy } \\
\text { metals that are high in instability } \\
\text { and solubility and in turn, result in } \\
\text { high bioavailability which increases } \\
\text { potential health risk. Decrease in } \\
\text { soil productivity by high Pb } \\
\text { concentration, while extreme low } \\
\text { concentration can inhibit some } \\
\text { essential plant processes such as } \\
\text { mitosis, water adsorption, and } \\
\text { photosynthesis. This can lead to } \\
\text { brown short roots and stunted } \\
\text { growth/foliage. Toxicity of heavy } \\
\text { metals on the other hand can lead to } \\
\text { reduced ability in leguminous plants } \\
\text { to fix molecular nitrogen }\end{array}$ & $\begin{array}{l}\text { Bawuro et al. [57]; Agbenin [70]; } \\
\text { Anguelov and Anguelova [64]; } \\
\text { Armah et al. [71]; Tangahu et al. } \\
\text { [72]; Khan et al. [73]; } \\
\text { Bhattacharyya et al. [74]; Guala } \\
\text { et al. [75]; Singh et al. [76]; Akan } \\
\text { et al. [77]; Opaluwa et al. [30, 61] }\end{array}$ \\
\hline
\end{tabular}

4.5. Cobalt (Co). Cobalt is an essential microelement for humans in the form of vitamin $\mathrm{B}_{12}$ with a complex pathway through the food to man $[79,86]$. Deficiency of Co results in pernicious anemia syndrome, whereby the intrinsic factor from the stomach that facilitates B12 absorption is absent, characterized by larger than normal (macrocytic) red blood cells plus neurologic abnormalities. Excessive Co added to the foam stabilizer in beer however produced severe cardiomyopathy, haematologic, neurologic, and thyroid abnormalities in humans $[79,88]$. A relationship between $\mathrm{Co} /$ iodine (I) ratios in geochemical environment showed an inverse correlation between Co in water and soil and thyroid enlargement in animal and man.

4.6. Copper ( $\mathrm{Cu}$ ) and Chromium ( $\mathrm{Cr}$ ). These are important essential elements but when consumed in excess, they cause toxicity $[89,90]$. It should be noted that the threshold for the effects of copper on the gastrointestinal tract still leaves some uncertainty regarding the long-term effects of $\mathrm{Cu}$ on sensitive populations, such as carriers of gene for Wilson disease and other metabolic disorders of copper homeostasis [81]. 
Copper deficiency results in kinky and steely hair syndrome in humans and abnormal wool in sheep, while excessive $\mathrm{Cu}$ intake results to hepatolenticular degeneration with progressive impairment of $\mathrm{Cu}$-laden tissues until death results [81]. It also helps in interconversion of the major neurotransmitters, dopamine, noradrenaline, and adrenaline, and in pigment production. Zinc- $\mathrm{Cu}$ interaction has shown hypothesis of ischemic heart disease, which proposes that decreased $\mathrm{Cu}$ intake with excessive $\mathrm{Zn}$ may play an aetiologic role in cardiac deaths in both animals and man $[79,88]$. Contamination and pollution of vegetable and soils near smelters does occur, and excessive $\mathrm{Cu}$ in drinking water has been reported to have caused a toxic syndrome in an infant called pink disease [84]. Chromium helps to maintain blood glucose levels, but its toxicity can result in allergic dermatitis such as eczema [91].

4.7. Cadmium (Cd). Cadmium may also be adsorbed onto organic substances, such as humic and fulvic acids, and therefore organic-rich waters may have higher $\mathrm{Cd}$ concentrations given a local Cd source $[79,85]$. Chronic exposure to the metal can lead to kidney disorders, anemia, emphysema, anosmia (loss of sense and smell), cardiovascular diseases, renal problems, and hypertension [84]. Itaiitai disease appears to be a Cd-related disease, which is very painful and causes the wastage and embrittlement of bones [78].

4.8. Arsenic (As). Arsenic is a metalloid whose chronic exposure effects include tingling, numbness, and peripheral neuropathy according to Plant and Thornton [84]. These authors also argued that arsenic toxicity in cattle has been found to cause dysentery and respiratory distress. An ecological correlation between the arsenic level of well water and mortality from various malignant neoplasm in China (Province of Taiwan) demonstrated a significant association with the arsenic level in well water ranging from 0.35 to $1.14 \mathrm{mg} / \mathrm{l}$ with a median of $0.78 \mathrm{mg} / \mathrm{l}$ for cancer of the liver, nasal cavity, lung, skin, bladder, and kidney and hyperpigmentation, hyperkeratosis, Blackfoot disease (a type of gangrene) in both males and females, and prostate cancer in males [92].

Heavy metal contamination is a global issue [93-97] and of high significance in Nigeria. Evidence from research within the context of Nigeria suggests a growing concern for protecting different varieties of food from the toxic effects of heavy metals $[30,69]$. The present outcome from various laboratory investigations, such as those of Ogunkunle et al. [56] and Obiora et al. [29], show that some of these heavy metal contaminations, particularly those affecting dairies, most of the aquatic habitat, and the beverage industry, are within safety level, according to international standards. However, chances are that they would heighten their toxicity because of the ever-increasing industrial and anthropogenic activities. Therefore, future toxicology assessment and food chain safety measures are being recommended [62].

Of all the heavy metals found in the literature, $\mathrm{Pb}, \mathrm{Cd}$, $\mathrm{Hg}$, and $\mathrm{Mn}$ have the highest health risk index (HRI) in
Nigeria because of their bioavailability. These heavy metals are present in most of the staple foods, such as cassava found in the southern and southeastern parts of Nigeria. This is a risky situation for people who live in these areas where the consumption of such foods is part of the endeared human culture. Other findings and concerns from the review include the following:

(1) Localised research, that is, state-based studies by previous authors. Localisation of study areas tends to reduce bias as data and validation for research on a country-wide scale could increase uncertainties which might complicate important issues.

(2) Heavy metal concentrations found in beverages, bouillon cubes, and food condiments in Nigeria are within the EU/WHO/FAO maximum permissive limits, and hence pose no health risk [44, 62]. However, those in some varieties of fish (Clarias gariepinus), cassava, fruits, and vegetables in different regions of the country show significant potential health risk.

(3) The main pathway through which these heavy metals contaminate the food chain in Nigeria is the soil, water, and other inorganic substances by the process of leaching and runoff while human exposure pathways to these heavy metals are ingestion, inhalation, and dermal [30]. Foods on sale in the open marketplace are at high risk of being contaminated by heavy metals [56].

(4) In the global literature, several scientific techniques are applied to reduce the toxicity of heavy metals in the food chain. Dash et al. [98] presented rhizobacteria which the authors argued was most suited for alleviating the stress of heavy metals in the agroecosystem. Li et al. [99] discussed a number of techniques involving chemical, physical, and biological methods including phytoremediation as a costeffective, environmentally friendly, and aesthetical measure. Evidence from the literature shows that these techniques are lacking in Nigeria. However, a few primordial and conventional toxicity reduction techniques are recorded, and this include education of farmers to reduce the use of pesticides [100] and proper disposal and siting of municipal wastes [101].

\section{Conclusion}

Heavy metal poisoning of the food chain has stimulated increasing research interests within the field of environmental chemistry and toxicology. Earth materials comprise an abundance of heavy metals that support the ecosystem processes. Several cases of human health impacts have resulted because of bioavailability, bioaccessibility, and excessive concentrations and distribution of contaminants in the food chain. These heavy metals contaminate most of the soils, farmlands, and aquatic habitats. The chemistry of these metals, rather than their density, is a major contributor to their usefulness, more so their negative impacts on the human-ecological systems. 
Although existing research on food chain contamination in Nigeria is fragmented and localised, this review has shown that heavy metal contamination affects Nigeria's food chain although at present, the amount of these toxic substances found in beverages, food condiments, and some aquatic animals is at a safety level. Sources of contaminants are both natural and anthropogenic. These toxic substances make their way to the farmland, water, and food stuff exposed in the market by mostly the process of leaching and runoff. Anthropogenic activities contaminate different environmental media such as the soil, water, and air which support the growth, production, and supply of foods. Ingestion, inhalation, and dermal are the major exposure pathways through which heavy metals in locally produced foods in most of the regions get to the consumers. Toxicity of these heavy metals can cause potential health hazards. Thus, longterm consumption of these foods is of public health significance. There is the need for better quality control for food crops to protect consumers from contamination exposure. In addition, close monitoring of the significant possibility of significant harm of these heavy metals on the health of the population in these regions is essential. It is also important to use remediation measures in contaminated areas where local foods are grown or produced.

In view of the implications of heavy metals in the food chain in Nigeria, researchers showed insufficient fundamental discussions on the understanding of the true nature of the health risk to inform practical and implementable decision and policy. It therefore shows that a country-wide knowledge base is lacking. This is a major limitation, which possess potential constraints on insight for future research focus. Therefore, this prevention study aimed to address the gaps in knowledge by synthesising existing knowledge and drawing from the examples presented in extant research. In addition, this review shows that more scientific techniques for mitigating the impacts of these heavy metals' contamination are lacking in Nigeria although research documents a few primordial and conventional toxicity reduction techniques. The spatial distribution of these toxicities in Nigeria's food chain is the major issue that suggest the need for further research, which should map and delineate spatially the variations in heavy metal toxicity within the whole of Nigeria. This will provide insight into those states and localities that mostly need food intervention. It will further enhance quality decision and policy making towards country-based food safety adaptation and capacity to cope with food toxicity and diseases resulting from heavy metal contamination of the food chain.

\section{Conflicts of Interest}

The authors declare that they have no conflicts of interest.

\section{References}

[1] S. J. Hawkes, "What is a "heavy metal?"” Journal of Chemical Education, vol. 74, no. 11, p. 1374, 1997.

[2] H. Ali and E. Khan, "What are heavy metals? Long-standing controversy over the scientific use of the term "heavy metals"-proposal of a comprehensive definition," Toxicological \& Environmental Chemistry, vol. 100, no. 1, pp. 6-19, 2018.

[3] A. Ghaffar Ebadi and H. Hikmat, "Physicochemical characterization of sediments from Tajan river basin in the northern Iran," Toxicological \& Environmental Chemistry, vol. 100, no. 5-7, pp. 540-549, 2018.

[4] F. A. A. Al-Rub, M. H. El-Naas, F. Benyahia, and I. Ashour, "Biosorption of nickel on blank alginate beads, free and immobilized algal cells," Process Biochemistry, vol. 39, no. 11, pp. 1767-1773, 2004.

[5] H. Ali and E. Khan, "Bioaccumulation of non-essential hazardous heavy metals and metalloids in freshwater fish. Risk to human health," Environmental Chemistry Letters, vol. 16, no. 3, pp. 903-917, 2018.

[6] T. Navratil and L. Minarik, "Trace elements and contaminants," in Earth Systems: History and Natural Variability, EOLSS Publishers, Oxford, UK, 2005.

[7] P. O. Odika, O. L. Anike, A. G. Onwuemesi, N. F. Odika, and R. B. Ejeckam, "Assessment of environmental geochemistry of lead-zinc mining at Ishiagu area, lower Benue trough, southeastern Nigeria," Earth Science Research, vol. 9, no. 1, pp. 1-31, 2020.

[8] F. Wang, Z. Wang, C. Kou, Z. Ma, and D. Zhao, "Responses of wheat yield, macro- and micro-nutrients, and heavy metals in soil and wheat following the application of manure compost on the North China plain," PLoS One, vol. 11, no. 1, Article ID e0146453, 2016.

[9] J. N. Ihedioha, P. O. Ukoha, and N. R. Ekere, "Ecological and human health risk assessment of heavy metal contamination in soil of a municipal solid waste dump in Uyo, Nigeria," Environmental Geochemistry and Health, vol. 39, no. 3, pp. 497-515, 2017.

[10] M. Ghaderpoori, B. Kamarehie, A. Jafari, A. Ghaderpoury, and M. Karami, "Heavy metals analysis and quality assessment in drinking water-Khorramabad city, Iran," Data in Brief, vol. 16, pp. 685-692, 2018.

[11] M. T. Gómez-Sagasti, I. Alkorta, J. M. Becerril, L. Epelde, M. Anza, and C. Garbisu, "Microbial monitoring of the recovery of soil quality during heavy metal phytoremediation," Water, Air, \& Soil Pollution, vol. 223, no. 6, pp. 3249-3262, 2012.

[12] F. S. Harahap and L. T. Lubis, "Analysis of heavy metals distribution in the river town of hamasaki's rod padangsidimpuan," EKSAKTA: Berkala Ilmiah Bidang MIPA, vol. 19, no. 2, pp. 50-56, 2018.

[13] L.-X. Liu, "Recent uses of iron catalysts in organic reactions," Current Organic Chemistry, vol. 14, no. 11, pp. 1099-1126, 2010.

[14] Y. S. Bae, N. D. Hill, Y. Bibi, J. Dreiher, and A. D. Cohen, "Innovative uses for zinc in dermatology," Dermatologic Clinics, vol. 28, no. 3, pp. 587-597, 2010.

[15] P. T. Cardeilhac and B. R. Whitaker, "Copper treatments: uses and precautions," Veterinary Clinics of North America: Small Animal Practice, vol. 18, no. 2, pp. 435-448, 1988.

[16] J. R. J. Sorenson, "Copper complexes as "radiation recovery" agents," Chemistry in Britain, vol. 25, no. 2, pp. 169-170, 1989.

[17] P. C. Nagajyoti, K. D. Lee, and T. V. M. Sreekanth, "Heavy metals, occurrence and toxicity for plants: a review," Environmental Chemistry Letters, vol. 8, no. 3, pp. 199-216, 2010.

[18] H. Ali, E. Khan, and I. Ilahi, "Environmental chemistry and ecotoxicology of hazardous heavy metals: environmental persistence, toxicity, and bioaccumulation," Journal of Chemistry, vol. 2019, Article ID 6730305, 14 pages, 2019. 
[19] M. Aycicek, O. Kaplan, and M. Yaman, "Effect of cadmium on germination, seedling growth and metal contents of sunflower (Helianthus annus L.)," Asian Journal of Chemistry, vol. 20, no. 4, pp. 2663-2672, 2008.

[20] I. Alkorta, J. Hernández-Allica, J. M. Becerril, I. Amezaga, I. Albizu, and C. Garbisu, "Recent findings on the phytoremediation of soils contaminated with environmentally toxic heavy metals and metalloids such as zinc, cadmium, lead, and arsenic," Reviews in Environmental Science and Bio/ Technology, vol. 3, no. 1, pp. 71-90, 2004.

[21] B. Volesky, "Biosorption and biosorbents," in Biosorption of Heavy Metals, B. Volesky, Ed., pp. 3-5, CRC Press, Boca Raton, FL, USA, 1990.

[22] Y.-L. Lai, M. Thirumavalavan, and J.-F. Lee, "Effective adsorption of heavy metal ions $\left(\mathrm{Cu}^{2+}, \mathrm{Pb}^{2+}, \mathrm{Zn}^{2+}\right)$ from aqueous solution by immobilization of adsorbents on $\mathrm{Ca}$ alginate beads," Toxicological \& Environmental Chemistry, vol. 92, no. 4, pp. 697-705, 2010.

[23] F. Sartori and E. Vidrio, "Environmental fate and ecotoxicology of paraquat: a California perspective," Toxicological \& Environmental Chemistry, vol. 100, no. 5-7, pp. 479-517, 2018.

[24] H. Ali, E. Khan, and M. A. Sajad, "Phytoremediation of heavy metals-concepts and applications," Chemosphere, vol. 91, no. 7, pp. 869-881, 2013.

[25] L. Dai, L. Wang, L. Li et al., "Multivariate geostatistical analysis and source identification of heavy metals in the sediment of Poyang Lake in China," Science of The Total Environment, vol. 621, pp. 1433-1444, 2018.

[26] M. Edelstein and M. Ben-Hur, "Heavy metals and metalloids: sources, risks and strategies to reduce their accumulation in horticultural crops," Scientia Horticulturae, vol. 234, pp. 431-444, 2018.

[27] Z. D. Nejad, M. C. Jung, and K. H. Kim, "Remediation of soils contaminated with heavy metals with an emphasis on immobilization technology," Environmental Geochemistry and Health, vol. 40, no. 3, pp. 927-953, 2018.

[28] M. M. Onakpa, A. A. Njan, and O. C. Kalu, "A review of heavy metal contamination of food crops in Nigeria," Annals of Global Health, vol. 84, no. 3, pp. 488-494, 2018.

[29] S. C. Obiora, A. Chukwu, and T. C. Davies, "Heavy metals and health risk assessment of arable soils and food crops around $\mathrm{Pb}-\mathrm{Zn}$ mining localities in Enyigba, southeastern Nigeria," Journal of African Earth Sciences, vol. 116, pp. 182-189, 2016.

[30] O. D. Opaluwa, M. O. Aremu, L. O. Ogbo et al., "Heavy metal concentrations in soils, plant leaves and crops grown around dump sites in Lafia metropolis, Nasarawa State, Nigeria," Advances in Applied Science Research, vol. 3, no. 2, pp. 780-784, 2012.

[31] O. E. Orisakwe, J. K. Nduka, C. N. Amadi, D. O. Dike, and O. Bede, "Heavy metals health risk assessment for population via consumption of food crops and fruits in Owerri, South Eastern, Nigeria," Chemistry Central Journal, vol. 6, no. 77, 2012.

[32] L.-M. Cai, Q.-S. Wang, J. Luo et al., "Heavy metal contamination and health risk assessment for children near a large $\mathrm{Cu}$-smelter in central China," Science of the Total Environment, vol. 650, pp. 725-733, 2019.

[33] M. Esmaeilzadeh, J. Jaafari, A. A. Mohammadi, M. Panahandeh, A. Javid, and S. Javan, "Investigation of the extent of contamination of heavy metals in agricultural soil using statistical analyses and contamination indices,"
Human and Ecological Risk Assessment: An International Journal, vol. 25, no. 5, pp. 1125-1136, 2019.

[34] World Health Organization, 2015, http://www.who.int/ countries/nga/en/.

[35] K. Manikas and K. M. Hansen, "Software ecosystems-a systematic literature review," Journal of Systems and Software, vol. 86, no. 5, pp. 1294-1306, 2013.

[36] U. Nkwunonwo, W. Malcolm, and B. Brian, "Flooding and flood risk reduction in Nigeria: cardinal gaps," Journal of Geography \& Natural Disasters, vol. 5, no. 1, pp. 136-148, 2015.

[37] N. Thonemann and M. Schumann, "Environmental impacts of wood-based products under consideration of cascade utilization: a systematic literature review," Journal of Cleaner Production, vol. 172, pp. 4181-4188, 2018.

[38] P. B. A. N. Kumar, V. Dushenkov, H. Motto, and I. Raskin, "Phytoextraction: the use of plants to remove heavy metals from soils," Environmental Science \& Technology, vol. 29, no. 5, pp. 1232-1238, 1995.

[39] H. V. Scheller, B. Huang, E. Hatch, and P. B. Goldsbrough, "Phytochelatin synthesis and glutathione levels in response to heavy metals in tomato cells," Plant Physiology, vol. 85, no. 4, pp. 1031-1035, 1987.

[40] J. Wang and C. Chen, "Biosorption of heavy metals by Saccharomyces cerevisiae: a review," Biotechnology Advances, vol. 24, no. 5, pp. 427-451, 2006.

[41] V. Dushenkov, P. B. A. N. Kumar, H. Motto, and I. Raskin, "Rhizofiltration: the use of plants to remove heavy metals from aqueous streams," Environmental Science \& Technology, vol. 29, no. 5, pp. 1239-1245, 1995.

[42] R. N. Asomugha, N. A. Udowelle, S. J. Offor et al., "Heavy metals hazards from Nigerian spices," Roczniki Państwowego Zakładu Higieny: Annals of the National Institute of Hygiene (Quarterly), vol. 67, no. 3, pp. 309-314, 2016.

[43] N. E. Okoronkwo, J. C. Igwe, and E. C. Onwuchekwa, "Risk and health implications of polluted soils for crop production," African Journal of Biotechnology, vol. 4, no. 13, 2011.

[44] I. C. Nnorom, O. Osibanjo, and K. Ogugua, "Trace heavy metal levels of some bouillon cubes, and food condiments readily consumed in Nigeria," Pakistan Journal of Nutrition, vol. 6, no. 2, pp. 122-127, 2007.

[45] J. N. Ihedioha and C. O. B. Okoye, "Dietary intake and health risk assessment of lead and cadmium via consumption of cow meat for an urban population in Enugu State, Nigeria," Ecotoxicology and Environmental Safety, vol. 93, pp. 101-106, 2013.

[46] A. D. Hart, C. A. Oboh, I. S. Barimalaa, and T. G. Sokari, "Concentrations of trace metals (lead, iron, copper and zinc) in crops harvested in some oil prospecting locations in Rivers State, Nigeria," African Journal of Food, Agriculture, Nutrition and Development, vol. 5, no. 2, pp. 1-21, 2005.

[47] H. I. Kelle, E. O. Ngbede, and O. V. Uju, "Determination of heavy metals in fish (Clarias gariepinus) organs from asaba major markets, delta state, Nigeria," Journal of Chemical Society of Nigeria, vol. 43, no. 1, 2018.

[48] C. A. Worgu, "Heavy metal concentration in some seafood commonly consumed in selected parts of River State," Journal of Applied Chemistry and Agricultural Research, vol. 2, no. 2, pp. 44-47, 2000.

[49] E. U. Alum, E. B. Essien, and B. W. Abbey, "Heavy metals content of food crops grown in oil exploration areas of Rivers State," International Journal of Science and Nature, vol. 5, no. 3, pp. 486-493, 2014. 
[50] E. E. Nkwocha, E. C. Pat-Mbano, and N. F. Tony-Njoku, "Assessment of heavy metal concentration in food crops grown around Etelebou oil flow station in Bayelsa State, Nigeria," International Journal of Science and Nature, vol. 2, no. 3, pp. 665-670, 2011.

[51] K. W. Nkpaa, K. C. Patrick-Iwuanyanwu, M. O. Wegwu, and E. B. Essien, "Health risk assessment of hazardous metals for population via consumption of seafood from Ogoniland, Rivers State, Nigeria; a case study of Kaa, B-Dere, and Bodo City," Environmental Monitoring and Assessment, vol. 188, no. 1, pp. 9-21, 2016.

[52] J. K. C. Nduka, O. E. Orisakwe, L. O. Ezenweke, M. N. Chendo, and T. E. Ezenwa, "Heavy metal contamination of foods by Refuse dump sites in awka, southeastern Nigeria," The Scientific World Journal, vol. 8, pp. 941-948, 2008.

[53] E. I. Adeyeye, "Trace metals in soils and plants from Fadama farms in Ekiti State, Nigeria," Bulletin of the Chemical Society of Ethiopia, vol. 19, no. 1, pp. 23-34, 2005.

[54] Q. Zhou, Z.-d. Liu, Y. Liu, J. Jiang, and R.-k. Xu, "Relative abundance of chemical forms of $\mathrm{Cu}$ (II) and $\mathrm{Cd}(\mathrm{II})$ on soybean roots as influenced by $\mathrm{pH}$, cations and organic acids," Scientific Reports, vol. 6, no. 1, p. 36373, 2016.

[55] H. A. Olayiwola, L. A. Gbola, K. Adewuyi, and M. O. Azeez, "Heavy metal contents in soil and plants at dumpsites: a case study of awotan and ajakanga dumpsite Ibadan, Oyo state, Nigeria," Journal of Environment \& Earth Sciences, vol. 7, no. 4, pp. 11-24, 2017.

[56] A. T. J. Ogunkunle, O. S. Bello, and O. S. Ojofeitimi, "Determination of heavy metal contamination of street-vended fruits and vegetables in Lagos state, Nigeria," International Food Research Journal, vol. 21, no. 5, 2014.

[57] A. A. Bawuro, R. B. Voegborlo, and A. A. Adimado, "Bioaccumulation of heavy metals in some tissues of fish in Lake Geriyo, Adamawa State, Nigeria," Journal of Environmental and Public Health, vol. 2018, Article ID 1854892, 7 pages, 2018.

[58] J. O. Jacob and S. E. Kakulu, "Assessment of heavy metal bioaccumulation in spinach, jute mallow and tomato in farms within Kaduna Metropolis, Nigeria," American Journal of Chemistry, vol. 2, no. 1, pp. 13-16, 2012.

[59] O. C. Matthews-Amune and S. Kakulu, "Heavy metals pollution in agricultural soil of adogo in ajaokuta local government area of Kogi State, Nigeria," International Journal of Pure and Applied Sciences and Technology, vol. 11, no. 1, p. 126, 2012.

[60] Y. A. Iyaka, "Concentration of $\mathrm{Cu}$ and $\mathrm{Zn}$ in some fruits and vegetables commonly available in north-central zone of Nigeria," Electronic Journal of Environmental, Agricultural and Food Chemistry, vol. 6, no. 6, pp. 2150-2154, 2007.

[61] O. Opaluwa, M. Aremu, L. Ogbo, I. Magaji, I. E. Odiba, and E. Ekpo, "Assessment of heavy metals in water, fish and sediments from UKE stream, Nasarawa state, Nigeria," Current World Environment, vol. 7, no. 2, pp. 213-220, 2012.

[62] S. Izah, I. Inyang, T. Angaye, and I. Okowa, "A review of heavy metal concentration and potential health implications of beverages consumed in Nigeria," Toxics, vol. 5, no. 1, pp. 1-12, 2016.

[63] F. Mapanda, E. N. Mangwayana, J. Nyamangara, and K. E. Giller, "The effect of long-term irrigation using wastewater on heavy metal contents of soils under vegetables in Harare, Zimbabwe," Agriculture, Ecosystems \& Environment, vol. 107, no. 2-3, pp. 151-165, 2005.

[64] G. Anguelov and I. Anguelova, "Assessment of land-use effect on trace elements concentrations in soil solution from ultisols in North Florida," Agriculture, Ecosystems \& Environment, vol. 130, no. 1-2, pp. 59-66, 2009.

[65] M. Jaishankar, T. Tseten, N. Anbalagan, B. B. Mathew, and K. N. Beeregowda, "Toxicity, mechanism and health effects of some heavy metals," Interdisciplinary Toxicology, vol. 7, no. 2, pp. 60-72, 2014.

[66] M. O. Atayese, A. I. Eigbadon, and J. K. Adesodun, "Heavy metal contamination of Amaranthus grown along major highways in Lagos, Nigeria," African Crop Science Journal, vol. 16, no. 4, pp. 225-235, 2010.

[67] K. S. Balkhair and M. A. Ashraf, "Field accumulation risks of heavy metals in soil and vegetable crop irrigated with sewage water in western region of Saudi Arabia," Saudi Journal of Biological Sciences, vol. 23, no. 1, pp. S83-S92, 2016.

[68] Y. Titilawo, A. Adeniji, M. Adeniyi, and A. Okoh, "Determination of levels of some metal contaminants in the freshwater environments of Osun State, Southwest Nigeria: a risk assessment approach to predict health threat," Chemosphere, vol. 211, pp. 834-843, 2018.

[69] A. O. Afolayan, "Accumulation of heavy metals from battery waste in topsoil, surface water, and garden grown maize at Omilende area, Olodo, Nigeria," Global Challenges, vol. 2, no. 3, Article ID 1700090, 2018.

[70] J. O. Agbenin, "Lead in a Nigerian savanna soil under longterm cultivation," Science of The Total Environment, vol. 286, no. 1-3, pp. 1-14, 2002.

[71] F. A. Armah, R. Quansah, and I. Luginaah, "A systematic review of heavy metals of anthropogenic origin in environmental media and biota in the context of gold mining in Ghana," International Scholarly Research Notices, vol. 2014, Article ID 252148, 37 pages, 2014.

[72] B. V. Tangahu, S. R. Sheikh Abdullah, H. Basri et al., "A review on heavy metals (As, $\mathrm{Pb}$, and $\mathrm{Hg}$ ) uptake by plants through phytoremediation," International Journal of Chemical Engineering, vol. 2011, pp. 1-31, 2011.

[73] S. Khan, Q. Cao, Y. M. Zheng, Y. Z. Huang, and Y. G. Zhu, "Health risks of heavy metals in contaminated soils and food crops irrigated with wastewater in Beijing, China," Environmental Pollution, vol. 152, no. 3, pp. 686-692, 2008.

[74] P. Bhattacharyya, K. Chakrabarti, A. Chakraborty, S. Tripathy, and M. A. Powell, "Fractionation and bioavailability of $\mathrm{Pb}$ in municipal solid waste compost and $\mathrm{Pb}$ uptake by rice straw and grain under submerged condition in amended soil," Geosciences Journal, vol. 12, no. 1, pp. 41-45, 2008.

[75] S. D. Guala, F. A. Vega, and E. F. Covelo, "The dynamics of heavy metals in plant-soil interactions," Ecological Modelling, vol. 221, no. 8, pp. 1148-1152, 2010.

[76] R. Singh, N. Gautam, A. Mishra, and R. Gupta, "Heavy metals and living systems: an overview," Indian Journal of Pharmacology, vol. 43, no. 3, pp. 246-256, 2011.

[77] J. C. Akan, F. I. Abdulrahman, O. A. Sodipo, A. E. Ochanya, and Y. K. Askira, "Heavy metals in sediments from river Ngada, Maiduguri metropolis, Bornu state, Nigeria," Journal of Environmental Chemistry and Ecotoxicology, vol. 2, no. 9, pp. 131-140, 2010.

[78] World Health Organization (WHO), Guidelines for Drinking-Water Quality, First Addendum to Geneva, World Health Organization, Geneva, Switzerland, 3rd edition, 2006.

[79] J. Plant, D. Smith, B. Smith, and L. Williams, "Environmental geochemistry at the global scale," Journal of the Geological Society, vol. 157, no. 4, pp. 837-849, 2000.

[80] L. Hubbs-Tait, J. R. Nation, N. F. Krebs, and D. C. Bellinger, "Neurotoxicants, micronutrients, and social environments: 
individual and combined effects on children's development," Psychological Science in the Public Interest, vol. 6, no. 3, pp. 57-121, 2005.

[81] World Health Organization (WHO), Guidelines on Drinking-Water Quality, World Health Organization, Geneva, Switzerland, 3rd edition, 2004.

[82] United States Department of Health and Human Services, Agency for Toxic Substances and Disease Registry, United States Department of Health and Human Services, Washington, DC, USA, 2005.

[83] American Public Health Association (APHA), Standard Methods for the Examination of Water and Waste Water, American Water Works Association-World Environmental Foundation, Washington, DC, USA, 1999.

[84] J. A. Plant and I. Thornton, "Geochemistry applied to agriculture," in Applied Environ mental Geochemistry, I. Thornton, Ed., pp. 231-266, Academic Press, London, UK, 1st edition, 1983.

[85] W. M. Carla, Environmental Geology, WMC. Brown Publishers, Dubugue, IA, USA, 5th edition, 2002.

[86] R. Vinodhini and M. Narayanan, "The impact of toxic heavy metals on the hematological parameters in common carp (Cyprinus carpio L.)," Journal of Environmental Health Science \& Engineering, vol. 6, no. 1, pp. 23-28, 2009.

[87] World Health Organization (WHO), Zinc in DrinkingWater. Background Document for Preparation of WHO Guidelines for Drinking-Water Quality, World Health Organization, Geneva, Switzerland, 2003.

[88] B. E. Davies, C. Bowman, T. C. Davies, and O. Selinus, "Medical geology: perspectives and prospects," in Essentials of Medical Geology, pp. 1-13, Springer, Dordrecht, Netherlands, 2013.

[89] L. R. McDowell, Minerals in Animal and Human Nutrition, Elsevier Publishers, Alpharetta, GA, USA, 2nd edition, 2003.

[90] R. W. McDowell, M. D. Taylor, and B. A. Stevenson, "Natural background and anthropogenic contributions of cadmium to New Zealand soils," Agriculture, Ecosystems \& Environment, vol. 165, pp. 80-87, 2013.

[91] C. L. Broadhurst and P. Domenico, "Clinical studies on chromium picolinate supplementation in diabetes mellitus-a review," Diabetes Technology \& Therapeutics, vol. 8, no. 6, pp. 677-687, 2006.

[92] C. J. Chen and C. J. Wang, "Ecological correlation between arsenic level in well water and age-adjusted mortality from malignant neoplasms," Cancer Research, vol. 50, no. 17, pp. 5470-5474, 1990.

[93] H. Ali and E. Khan, "Assessment of potentially toxic heavy metals and health risk in water, sediments, and different fish species of River Kabul, Pakistan," Human and Ecological Risk Assessment: An International Journal, vol. 24, no. 8, pp. 2101-2118, 2018.

[94] H. Ali and E. Khan, "Trophic transfer, bioaccumulation, and biomagnification of non-essential hazardous heavy metals and metalloids in food chains/webs-concepts and implications for wildlife and human health," Human and Ecological Risk Assessment: An International Journal, vol. 25, no. 6, pp. 1353-1376, 2019.

[95] A. Ismail, M. Riaz, S. Akhtar, J. E. Goodwill, and J. Sun, "Heavy metals in milk: global prevalence and health risk assessment," Toxin Reviews, vol. 38, no. 1, pp. 1-12, 2019.

[96] L. Järup, "Hazards of heavy metal contamination," British Medical Bulletin, vol. 68, no. 1, pp. 167-182, 2003.

[97] P. K. Rai, S. S. Lee, M. Zhang, Y. F. Tsang, and K.-H. Kim, "Heavy metals in food crops: health risks, fate, mechanisms, and management," Environment International, vol. 125, pp. 365-385, 2019.

[98] B. Dash, R. Soni, and R. Goel, "Rhizobacteria for reducing heavy metal stress in plant and soil," in Plant Growth Promoting Rhizobacteria for Sustainable Stress Management, pp. 179-203, Springer, Singapore, 2019.

[99] C. Li, K. Zhou, W. Qin et al., "A review on heavy metals contamination in soil: effects, sources, and remediation techniques," Soil and Sediment Contamination: An International Journal, vol. 28, no. 4, pp. 380-394, 2019.

[100] G. E. Obi-Iyeke, "Heavy metal concentrations in streetvended fruits and vegetables in Warri, Delta State, Nigeria," Journal of Applied Sciences and Environmental Management, vol. 23, no. 3, pp. 443-447, 2019.

[101] A. O. Numbere, "The impact of nutrient and heavy metal concentrations on waste dump soils in mangrove and nonmangrove forest in the Niger delta, Nigeria," Journal of Energy and Natural Resources, vol. 8, no. 3, p. 109, 2019. 